\title{
PENYAKIT KARIES GIGI PADA PERSONIL DETASEMEN GEGANA SATUAN BRIMOB POLDA SULAWESI UTARA TAHUN 2019
}

\author{
Luciano Tommy Marthinu ${ }^{1}$, Mustapa Bidjuni ${ }^{2}$ \\ (1) Makosatbrimob Polda Sulut. Jl. AA Maramis.Paniki II Kota Manado \\ (2) Jurusan Kesehatan Gigi Poltekkes Kemenkes ManadoJl.RW Mongisidi Malalayang II Manado \\ Email : martihinuluciano@gmail.com
}

\begin{abstract}
ABSTRAK
Karies gigi terjadi oleh karena bakteri-bakteri tertentu yang mempunyai sifat membentuk asam sehingga terjadi $\mathrm{pH}$ rendah yang dapat menyebabkan pelarutan mineral enamel secara perlahan dan membentuk lubang pada gigi. Karies gigi dapat di alami oleh setiap orang termasuk personil Detasemen Gegana Satuan Brimob Polda Sulut. Tujuan :Tujuan penelitian mengetahui gambaran Penyakit Karies Gigi pada Personil Detasemen Gegana Satuan Brimob Polda Sulut. Metode: Jenis penelitian bersifat deskriptif menggambarkan kondisi diperoleh di lapangan secara nyata. Pengambilan sampel secara accidental sampling berjumlah 47 responden dari populasi 88 responden. Pengumpulan data dilakukan dengan cara pemeriksaan karies gigi dan hasil pemeriksaan dicatat dalam format pencatatan DMF-T. Data yang diperoleh diolah dan disajikan dalam tabel distribusi frekuensi persentase disertai keterangan. Hasil: Hasil penelitian menunjukkan bahwa kelompok umur paling banyak yaitu umur 20-30 tahun sebanyak 68,8, berdasarkan jenis kelamin responden laki-laki jumlahnya lebih banyak 91,4\% daripada perempuan. Berdasarkan pangkat responden paling banyak yaitu pangkat Bintara sebanyak $72,34 \%$ diikuti pangkat Tamtama sebanyak 23,4\% dan paling sedikit pangkat perwira yaitu $4,25 \%$. Berdasarkan pengalaman karies gigi yang dinilai dengan menggunakan indeks DMF-T dari WHO diketahui bahwa paling banyak pada kategori rendah yaitu 44,6\%, kategori sangat rendah ada 42,5\%, kategori sedang 6,38\% dan kategori tinggi yaitu 6,38\%. Rata-rata indeks DMF-T yaitu 6,3 dimana setiap responden memiliki 6 buah gigi yang mengalami karies gigi.
\end{abstract}

Kesimpulan: Keadaan karies gigi pada personil Detasemen Gegana berdasarkan indeks DMF-T yaitu 6,34 kategori rendah.

\section{Kata Kunci:Penyaki, Karies Gigi, DMF-T.}

\begin{abstract}
Introduction : Dental caries occurs due to certain bacteria that have acid-forming properties resulting in a low $\mathrm{pH}$ which can cause the slowly dissolving of enamel minerals and forming holes in the teeth. Anyone can experience dental caries, including personnel from the Detachment Gegana of the North Sulawesi Police Mobile Brigade Unit. Purpose: The aim of this research is to know the description of dental caries in the personnel of the Gegana Detachment of the Police Mobile Brigade Unit of the North Sulawesi Police. Method: This type of research is descriptive describing the conditions obtained in the field in real terms. Sampling by accidental sampling amounted to 47 respondents from a population of 88 respondents. Data was collected by means of examination of dental caries and the results of the examination were recorded in the DMF-T recording format. The data obtained is processed and presented in a percentage frequency distribution table accompanied by information. Results: The results showed that the most age group, namely the age group of
\end{abstract}


20-30 years as many as 68.8 , based on the sex of male respondents, the number was $91.4 \%$ more than that of women. Based on the rank of the most respondents, namely the rank of non-commissioned officers as much as $72.34 \%$, followed by the rank of Tamtama as much as $23.4 \%$ and the least rank of the officers, namely $4.25 \%$. Based on the experience of dental caries assessed using the DMF-T index from WHO, it is known that the most in the low category is $44.6 \%$, the very low category is $42.5 \%$, the moderate category is $6.38 \%$ and the high category is $6.38 \%$. The average DMF-T index is 6.3 where each respondent has 6 teeth with dental caries. Conclusion: The condition of dental caries in the Gegana Detachment personnel based on the DMF-T index is 6.34 in the low category.

Keywords: Disease, Dental Caries, DMF-T.

\section{PENDAHULUAN}

Kesehatan mulut adalah indikator utama kesehatan secara keseluruhan, kesejahteraan dan kualitas hidup. WHO mendefinisikan kesehatan mulut sebagai "keadaan terbebas dari sakit mulut dan wajah kronis, kanker mulut dan tenggorokan, infeksi dan luka mulut, penyakit periodontal (gusi), kerusakan gigi, kehilangan gigi, serta penyakit dan gangguan lain yang membatasi kapasitas individu dalam menggigit, mengunyah, tersenyum, berbicara, dan kesejahteraan psikososial. $^{1}$

Penyakit dan kondisi mulut: Tujuh penyakit dan kondisi mulut menyebabkan sebagian besar beban penyakit mulut.Mereka termasuk karies gigi (kerusakan gigi), penyakit periodontal (gusi), kanker mulut, manifestasi oral HIV, trauma oro-dental, bibir sumbing dan langit-langit mulut, dan noma. Hampir semua penyakit dan kondisi sebagian besar dapat dicegah atau dapat diobati pada tahap awal. Global Burden of Disease Study 2016 memperkirakan bahwa penyakit mulut mempengaruhi setidaknya 3,58 miliar orang di seluruh dunia, dengan karies gigi permanen menjadi yang paling umum dari semua kondisi yang dinilai. Secara global, diperkirakan 2,4 miliar orang menderita karies gigi permanen dan 486 juta anak menderita karies gigi sulung. Karies gigi terjadi ketika biofilm mikroba (plak) yang terbentuk pada permukaan gigi mengubah gula bebas yang terkandung dalam makanan dan minuman menjadi asam yang melarutkan enamel gigi dan dentin dari waktu ke waktu. Dengan asupan gula bebas yang terus menerus tinggi, paparan fluoride yang tidak memadai dan tanpa biofilm mikroba yang dapat dilepas secara teratur, struktur gigi dihancurkan, yang mengakibatkan perkembangan gigi berlubang dan nyeri, berdampak pada kualitas hidup yang berhubungan dengan kesehatan mulut, dan, pada tahap lanjut, kehilangan gigi dan infeksi sistemik. WHO. ${ }^{1}$

Berdasarkan data dari Pusat Data Informasi Kementerian Kesehatan R.I Tahun 2019 pemerintah telah mentargetkan bahwa pada tahun 2020 DMF-T penduduk Indonesia 4,1 dan Tahun 2025 penduduk Indonesia DMF-T 3,7, Tahun 2030 DMF-T penduduk Indonesia 3,3. Melihat data DMF-T melalui Riskesdas terlihat bahwa data tersebut masih di atas target yang akan dicapai oleh pemerintah, maka strategi yang telah dibuat oleh kementerian kesehatan berdasarkan keputusan menteri kesehatan nomor 189 Tahun 2019 tentang komite kesehatan gigi dan mulut, strateginya sebagai berikut; 1 . Meningkatkan upaya promotif, 2. Meningkatkan kualitas pelayanan, 3). Meningkatkan peranserta stake holder terkait pelayanan kesehatan gigi dan mulut. $^{2}$ 
Kesehatan gigi dan mulut berperan dalam menentukan status kesehatan seseorang. Untuk menilai status kesehatan gigi dapat dilihat dari ada tidaknya penyakit gigi, diantaranya karies gigi. Karies gigi adalah suatu penyakit jaringan gigi yang ditandai dengan kerusakan jaringan dimulai dari permukaan gigi (pit, fissure dan daerah interproximal) dan meluas ke daerah pulpa. Karies gigi dapat dialami oleh setiap orang dan dapat timbul pada suatu permukaan gigi atau lebih serta dapat meluas kebagian paling dalam dari gigi. ${ }^{3}$. Kesehatan mulut sangat penting bagi kesehatan dan kesejahteraan tubuh secara umum dan sangat mempengaruhi kualitas kehidupan, termasuk fungsi bicara, pengunyahan, dan rasa percaya diri. Gangguan kesehatan mulut akan berdampak pada kinerja seseorang. Kesehatan mulut tidak sepenuhnya bergantung pada perilaku seseorang. ${ }^{4}$

Karies menjadi salah satu bukti tidak terawatnya kondisi gigi dan mulut masyarakat Indonesia. Penyebab karies gigi salah satunya karena sisa makanan yang menempel pada permukaan gigi. Upaya yang dapat dilakukan untuk membersihkan sisa makanan yang menempel pada permukaan gigi salah satunya dengan menggosok gigi dengan teknik yang benar dan waktu yang tepat. Namun menggosok gigi menggunakan teknik yang benar dan waktu yang tepat seringkali diabaikan oleh masyarakat, seringkali sisa makanan tidak terangkat dengan baik. Bahkan menggosok gigi dengan teknik yang salah dapat menyebabkan abrasi pada gigi sehingga menimbulkan karies.

Berdasarkan The Global Burden of Disease Study 2016 masalah kesehatan gigi dan mulut khususnya karies gigi merupakan penyakit yang dialami hampir dari setengah populasi penduduk dunia (3,58 milyar jiwa) (WHO, Fahrion, A 2019). Hasil data Riset Kesehatan Dasar (Riskesdas) Tahun 2013 bahwa sebesar 25,9\% penduduk Indonesia mempunyai masalah kesehatan gigi dan mulut, untuk provinsi Sulawesi Utara lebih tinggi dari angka nasional dengan angka 31,6\%. Sedangkan menurut Riskesdas tahun 2018 terjadi peningkatan menjadi $45,3 \%$ untuk provinsi Sulawesi Utara juga mengalami peningkatan dari 31,6\% menjadi $66,5 \% .^{5}$

Berdasarkan data pasien yang memeriksakan gigi di Klinik Satuan Brimob Polda Sulut tahun 2019 sampai Januari 2020 berjumlah 118 orang dari keseluruhan personil Satuan Brimob Polda Sulut yaitu 750 orang. Berdasarkan jumlah kunjungan tersebut diketahui $15,73 \%$ mengalami kasus karies gigi.

Tujuan penelitian ini adalah untuk mengetahui persentase karies gigi pada personel Detasemen Gagana Satuan Brimol Polda Sulawesi Utara.

\section{METODOLOGI}

Jenis penelitian ini merupakan penelitian deskriptif yang bertujuan untuk mendeskriptifkan atau memberi gambaran terhadap objek yang diteliti melalui data sampel atau populasi sebagaimana adanya. Penelitian dilaksnakan bulan Maret 2020 bertempat di Klinik Gigi Kesatuan Brimob Polda Sulawesi Utara. Pengambilan sampel secara accidental sampling berjumlah 47 responden dari populasi 88 responden. Variabel penelitian yaitu penyakit karies gigi berdasarkan umur, jenis kelamin dan pangkat. Intrumen penelitian berupa alat diagnosa set dan format pencatatan DMF-T.

\section{HASIL}


Distribusi responden menurut kelompok umur pada Detasemen Gegana Sat Brimobda Sulut dapat dilihat pada tabel 1:

Tabel 1. Distribusi Responden Menurut Kelompok Umur

\begin{tabular}{ccc}
\hline Umur & Jumlah & $\begin{array}{c}\text { Prosentase } \\
(\boldsymbol{\%})\end{array}$ \\
\hline 20-30 Tahun & 32 & 68,8 \\
31-40 Tahun & 7 & 14,89 \\
41-50 Tahun & 8 & 17,02 \\
\hline Total & $\mathbf{4 7}$ & $\mathbf{1 0 0}$ \\
\hline
\end{tabular}

Tabel 1 menunjukkan bahwa responden paling banyak berada pada umur 20 - 30 tahun sebanyak 68,8\% selanjutnya untuk umur 31 - 40 tahun sebanyak $14,89 \%$ dan untuk umur 41 - 50 tahun sebanyak 17,02 $\%$.

Distribusi responden menurut jenis kelamin pada personil Detasemen Gegana Satuan Brimobda Sulut dapat dilihat pada tabel 2 dibawah ini.

Tabel 2. Distribusi Responden Menurut Jenis Kelamin

\begin{tabular}{ccc}
\hline Jenis Kelamin & Jumlah & $\begin{array}{c}\text { Prosentase } \\
(\boldsymbol{\%})\end{array}$ \\
\hline Laki-laki & 43 & 91,4 \\
Perempuan & 4 & 8,51 \\
\hline Total & $\mathbf{4 7}$ & $\mathbf{1 0 0}$ \\
\hline
\end{tabular}

Tabel 2 menunjukkan bahwa responden paling banyak yaitu laki-laki sebanyak $91,4 \%$, sedangkan responden perempuan sebanyak $8,51 \%$

Distribusi responden menurut pangkat pada Detasemen Gegana Satuan Brimob Polda Sulut dapat dilihat pada tabel 3 dibawah ini.
Tabel 3. Distribusi Responden Menurut Pangkat

\begin{tabular}{ccc}
\hline Pangkat & Jumlah & $\begin{array}{c}\text { Prosentase } \\
(\boldsymbol{\%})\end{array}$ \\
\hline Tamtama & 11 & 23,4 \\
Bintara & 34 & 72,34 \\
Perwira & 2 & 4,25 \\
\hline Total & $\mathbf{4 7}$ & $\mathbf{1 0 0}$ \\
\hline
\end{tabular}

Tabel 3 menunjukkan bahwa responden yang paling banyak berada pada pangkat Bintara sebanyak 72,34 \%, diikuti pangkat Tamtama sebanyak 23,4 \% dan yang paling sedikit responden berpangkat perwira sebanyak $4,25 \%$.

Keadaan karies gigi berdasarkan indeks DMF-T secara terperinci diperoleh decay 162 gigi, missing 96 gigi, filling 27 gigi total 298 gigi yang mengalami karies gigi sehingga didapatkan hasil berdasarkan indeks DMF-T yaitu 298/47 responden maka DMF-Trata-rata diperoleh 6,34 yang artinya setiap personil mengalami karies sebanyak 6 buah gigi per individu. Sedangkan distribusi karies gigi berdasarkan indeks DMF-T pada personil Detasemen Gegana Satuan Brimob Polda Sulut dapat dilihat pada tabel 4 di bawah ini :

Tabel 4. Distribusi Karies Gigi Berdasarkan Indeks DMF-T

\begin{tabular}{ccc}
\hline Kategori & Jumlah & $\begin{array}{c}\text { Prosentase } \\
(\mathbf{\%})\end{array}$ \\
\hline Sangat rendah & 20 & 42,5 \\
Rendah & 21 & 44,6 \\
Sedang & 3 & 6,38 \\
Tinggi & 3 & 6,38 \\
\hline Total & $\mathbf{4 7}$ & $\mathbf{1 0 0}$ \\
\hline
\end{tabular}

Tabel 4 menunjukkan bahwa jumlah karies gigi pada responden yang dinilai 
berdasarkan indeks DMF-T paling banyak pada kategori rendah yaitu $44,6 \%$, sangat rendah 42,5 \%, kategori sedang 6,38 \%, sedangkan untuk kategori tinggi 6,38\%.

\section{PEMBAHASAN}

Masalah kesehatan gigi dan mulut masyarakat luas adalah karies gigi. Karies gigi merupakan penyakit jaringan keras gigi yaitu email, dentin dan sementum yang disebabkan oleh aktivitas suatu jasad renik dalam suatu karbohidrat yang dapat diragikan. Tandanya adalah terjadinya demineralisasi jaringan keras gigi yang kemudian diikuti oleh bahan organiknya. Akibatnya terjadi invasi bakteri dan kematian pulpa serta penyebaran infeksinya kejaringan periapeks yang dapat menyebabkan rasa nyeri. ${ }^{6}$ Karies gigi masih menjadi masalah di seluruh dunia tanpa memandang umur, bangsa maupun keadaan ekonomi. ${ }^{3}$

Hasil penelitian yang dilakukan kepada personil Detasemen Gegana Satuan Brimob Polda Sulawesi Utara menunjukkan bahwa menurut kategori DMF-T paling tinggi yaitu kategori karies rendah 21 responden $(44,6 \%)$ diikuti kategori sangat rendah yaitu 20 responden $42,5 \%$, untuk kategori sedang yaitu 3 responden $6,38 \%$ dan kategori tinggi yaitu 3 responden $6,38 \%$. Dengan kata lain tingkat kesehatan gigi dan mulut pada personil Detasemen Gegana masih terjaga dengan baik. Dapat dikatakan bahwa responden sudah mempunyai perilaku hidup sehat khususnya kesehatan gigi dan mulut. Perilaku merupakan hasil dari segala macam pengalaman dan interaksi manusia dengan lingkungannya wujudnya bisa berupa pengetahuan, sikap dan tindakan. Perilaku kesehatan adalah respon seseorang atau individu terhadap stimulus yang berhubungan dengan konsep sehat, sakit dan penyakit. Penyebab seseorang atau individu berperilaku sehat yaitu mempunyai pikiran dalam bentuk pengetahuan terhadap kesehatan, mencontoh orang lain yang berperilaku sehat, sumber daya kesehatan yang memadai serta kebudayaan dari masyarakat sekitar yang menunjang perilaku hidup sehat. $^{7}$

Penelitian ini sejalan dengan penelitian yang dilakukan oleh Sarini ((2018) dengan judul : Gambaran Karies Gigi pada Pasien yang Berkunjung di UPT Puskesmas Banjarangkang I Kabupaten Klungkung, dalam tulisannya berdasarkan kriteria WHO rata-rata karies gigi pada pasien yang berobat di Puskesmas Banjarangkan I Kabupaten Klungkung tahun 2018 tergolong dalam kategori rendah. Rendahnya angka karies ini kemungkinan disebabkan sudah cukup baiknya pengetahuan masyarakat tentang pemeliharaan kesehatan gigi dan mulut. Dalam tulisannya juga dikatakan bahwa pada umur 20-54 tahun adalah usia produktif sehingga mereka masih aktif untuk merawat kesehatan gigi dan mulutnya. $^{8}$

Pada hasil penelitian ini juga dapat diketahui jumlah karies gigi pada personil Detasemen Gegana berdasarkan umur dengan kategori tinggi adalah umur 31-40 yaitu sebanyak $28,6 \%$. Hal ini terjadi oleh karena retraksi atau menurunnya gusi dan papil gigi sehingga sisa-sisa makanan lebih sukar untuk dibersihkan. ${ }^{3}$ ). Hasil ini sesuai dengan penelitian yang dilakukan oleh Radiah, dkk (2013) dengan judul Gambaran status Karies Gigi dan Pola Pemeliharaan Kesehatan Gigi dan Mulut pada Mahasiswa asal Ternate di Manado, 
dalam tulisannya dikatakan bahwa pengaruh umur terhadap status karies gigi disebabkan oleh beberapa hal yaitu berkurangnya produksi air ludah dan lebih lama terpapar makanan dan minuman manis dalam proses pengunyahan yang dapat menyebabkan kerusakan gigi semakin banyak dan semakin parah. ${ }^{9}$

Jumlah karies gigi berdasarkan jenis kelamin dengan kategori tinggi adalah responden laki-laki yaitu sebanyak $7,0 \%$. Hal ini dipengaruhi oleh perilaku hidup sehat khususnya pada kesehatan gigi dan mulut dari responden yang belum optimal misalnya kebiasaan merokok. Hal ini sesuai dengan penelitian yang dilakukan oleh Jovina dan Made Ayu (2019) dengan judul Hubungan antara Perilaku Sikat Gigi, Merokok dan Diabetes Melitus dengan Status Karies Gigi di Indonesia dalam tulisannya dikatakan asap rokok yang terus menerus dapat menyebabkan perubahan reseptor dari indra perasa sehingga laju aliran saliva menurun. Hal ini mempengaruihi kapasitas buffer saliva untuk menurunkan $\mathrm{pH}$ saliva, merupakan salah satu faktor penyebab meningkatnya resiko terjadinya karies gigi. ${ }^{11}$ Didukung juga dengan hasil penelitian yang dilakukan oleh Notohartojo (2018) dengan judul Merokok dan Karies Gigi di Indonesia dikatakan bahwa kebiasaan merokok sangat mempengaruhi kesehatan mulut terutama perubahan mukosa selain itu kebiasaan merokok bisa memicu karies yang menyebabkan gigi berlubang dengan kata lain proporsi karies gigi lebih tinggi pada orang yang merokok. ${ }^{12}$

Hasil ini sesuai dengan penelitian yang dilakukan oleh Jotlely, dkk (2017) dengan judul Gambaran Status Karies berdasarkan DMF-T dan Indeks PUFA pada Orang
Papua di Asrama Cendrawasi Kota Manado dalam tulisannya dikatakan bahwa tingkat kesadaran untuk menjaga kebersihan gigi dan mulut lebih besar pada perempuan dari pada laki-laki dimana perempuan lebih memperhatikan penampilannya sedangkan laki-laki cenderung kurang memperhatikan. ${ }^{13}$ Didukung juga dengan penelitian yang dilakukan oleh Sukmana (2016) dengan judul Gambaran Karies dengan menggunakan DMF-T pada Masyarakat Pesisir Pantai kelurahan Takisung Kecamatan Takisung Kabupaten Tanah Laut dalam tulisannya dikatakan bahwa perempuan cenderung lebih telaten dalam menjaga kesehatan giginya karena menyangkut estetik seseorang. ${ }^{14}$ Sedangkan jumlah karies gigi berdasarkan pangkat dengan kategori tinggi adalah pangkat perwira yaitu sebanyak 50\%.

\section{KESIMPULAN.}

Berdasarkan hasil penelitian gambaran penyakit karies gigi pada personil Detasemen Gegana Satuan Brimob Polda Sulut dapat disimpulkan bahwa tingkat penyakit karies gigi berdasarkan kategori WHO berada pada kategori rendah. Ini menandakan bahwa personil Detasemen Gegana mempunyai pengetahuan yang baik tentang pemeliharaan kesehatan gigi dan mulut. Keadaan karies gigi berdasarkan indeks DMF-T secara terperinci diperoleh decay 162 gigi, missing 96 gigi, filling 27 gigi total 298 gigi yang mengalami karies, sehingga didapatkan hasil berdasarkan indeks DMF-T yaitu 6,34. Yang artinya setiap personil mengalami karies 6 buah gigi per individu. Dalam hasil penelitian ini juga dapat diketahui bahwa : 
Berdasarkan jenis kelamin karies gigi paling tinggi yaitu laki-laki pada kategori rendah 21 responden $(48,8 \%)$ dan jenis kelamin perempuan paling tinggi pada kategori sangat rendah 3 responden $(75,0 \%)$. Berdasarkan umur karies gigi paling tinggi yaitu umur 31-40 tahun sebanyak 28,6\%. Berdasarkan pangkat karies gigi paling tinggi yaitu pangkat perwira sebanyal $50 \%$.

\section{SARAN}

\section{DAFTAR PUSTAKA}

1. Fahrion,A.

WHO.

https://www.who.int/news-room/factsheets/detail/oral-health akses trg;1 26 April 2019

2. Budijanto, D. (2019). Pusat Data dan Informasi Kemenkes R.I

3. Tarigan R, (2012) Karies Gigi, EGC. Jakarta

4. Putri dkk, 2009. .Ilmu Pencegahan Jaringan Keras dan Jaringan Pendukung Gigi. EGC, Jakarta

5. Kementerian Kesehatan RI. (2018). Riset Kesehatan Dasar. Badan Penelitian dan Pengembangan Tenaga Kesehatan Kemenkes. Jakarta

6. Kidd E, Bechal. (1991). DASAR DASAR KARIES Penyakit dan Penanggulangannya. Edisi 1. EGC Jakarta

7. Budiharto. (2010). Pengantar Ilmu Perilaku Kesehatan dan Pendidikan Kesehatan Gigi. EGC Jakarta.
8. Sarini NK, 2019. Gambaran Karies Gigi Pada Pasien Yang Berkunjung di UPT Puskesmas Banjarangkan I Kabupaten Klunkung Tahun 2018. KTI Poltekkes Kemenkes Bali

9. Radiah,dkk. (2013) Gambaran Status Karies Dan Pola Pemeliharaan Kesehatan Gigi dan Mulut Pada Mahasiswa Asal Ternate di Manado. Jurnal e-GiGi (eG), Volume 1, Nomor 1, Maret 2013, hlm. 45-51

10. Jovina.TA dan Suratri.MAL. (2019) Hubungan antara Perilaku Sikat Gigi, Merokok, dan Diabetes Melitus dengan Status Karies Gigi di Indonesia: Analisis Data Riskesdas 2013. Jurnal Penelitian dan Pengembangan Pelayanan Kesehatan, Vol. 3, No. 1, April 2019

11. Notohartojo \& Indirawati Tjahja. (2018). Merokok dan Karies Gigi di Indonesia. Jurnal Penelitian dan Pelayanan Kesehatan Vol 2 No 3

12. Jotlely, Wowor, Gunawan. (2017). Gambaran Status Karies Berdasarkan Indeks DMF-T dan Indeks PUFA pada Orang Papua di Asrama Cendrawasi Kota Manado. Jurnal e-GiGi Vol 5 No 2.

13. Sukmana B.I (2016). Gambaran Karies Dengan Menggunakan DMF-T Pada Masyarakat Pesisir Pantai Kelurahan Takisung Kecamatan Takisung Kabupaten Tanah Laut. DENTINO JURNAL KEDOKTERAN GIGI Vol I. No 2. September 2016 